\title{
Peran Bank Rakyat Indonesia Syariah KC Palu Wolter Monginsidi Dalam Penghimpunan Dana Zakat Infak dan Shadaqah di Kota Palu
}

\author{
Fikriyah Muhtadin ${ }^{1 *}$,Noval Noval ${ }^{2}$, Ahmad Haekal $^{3}$ Moh. Anwar Zainuddin ${ }^{4}$ \\ ${ }^{1}$ Jurusan Ekonomi Syariah, Fakultas Ekonomi dan Bisnis Islam, IAIN Palu \\ ${ }^{2}$ Jurusan Perbankan Syariah, Fakultas Ekonomi dan Bisnis Islam, IAIN Palu, \\ ${ }^{3}$ Jurusan Ekonomi Syariah, Fakultas Ekonomi dan Bisnis Islam, IAIN Palu \\ ${ }^{4}$ Jurusan Ekonomi Syariah, Fakultas Ekonomi dan Bisnis Islam, IAIN Palu
}

ABSTRAK

Penelitian ini ditujukan untuk mengetahui peran BRI Syariah cabang Mongonsidi Palu dalam menghimpun Zakat, Infaqa, dan Sadaqah (ZIS) di kota Palu. Penelitian ini menggunakan metide kualitatif dengan Teknik pengumpulan data melalui observasi, wawancara mendalam, dan melalui dokumen tertulis yang diperoleh di lokasi penelitian yang berkaitan dengan penghimpunan ZIS. Wawancara dilakukan dengan pimpinan bank, bagian promosi, dan karyawan yang terlibat dalam penghimpunan ZIS. Hasil penelitian ini menunjukkan bawah penghimpunan dana ZIS di BRI Syariah yaitu dengan cara melakukan pembukaan rekening tabungan, sesuai dengan pilihan nasabah yang ingin melakukan zakat, infak dan sedekah. Kemudian BRI Syariah juga aktif mempromosikan penghimpunan ZIS melalui berbagai media social, spanduk, dan media massa lainnya.
INFORMASI

ARTIKEL

\section{Katakunci:}

Zakat, Infaq, Sadaqah, Penghimpunan, BRI Syariah 


\section{PENDAhuluan}

Perbankan syariah di Indonesia merupakan suatu perwujudan dari permintaan masyarakat yang membutuhkan suatu sistem perbankan alternatif yang selain menyediakan jasa perbankan/keuangan yang sehat, juga, memenuhi prinsip-prinsip syariah. ${ }^{1}$ Prinsip utama yang dianut Bank Syariah adalah larangan riba (bunga) dalam berbagai bentuk transaksi, menjalankan bisnis dan aktivitas perdagangan yang berbasis pada perolehan keuntungan yang sah menurut syariah dan menumbuh kembangkan zakat. $^{2}$

Pada tahun 1998, Pemerintah dan Dewan Perwakilan Rakyat melakukan penyempurnaan Undang-Undang No. 10 Tahun 1998 tentang Perubahan atas UndangUndang No. 7 Tahun 1992 tentang Perbankan, yang secara tegas menjelaskan bahwa terdapat dua sistem dalam perbankan di tanah air (dual banking system), yaitu sistem perbankan konvensional dan sistem perbankan syariah. Peluang ini disambut hangat masyarakat perbankan, yang ditandai dengan berdirinya beberapa Bank Islam lain, yakni Bank IFI, Bank Syariah Mandiri, Bank

\footnotetext{
${ }^{1}$ Ikatan Banker Indonesia, Memahami Bisnis Syariah (Jakarta: PT Gramedia Pustaka Utama, 2014), 3.

${ }^{2}$ Wirdyaningsih, Bank dan Asuransi Islam Di Indonesia, (Jakarta: Kencana, 2005), 47.
}

Niaga, Bank BTN, Bank Mega, Bank BRI, Bank Bukopin, BPD Jabar dan BPD Aceh. Salah satu fungsi dari perbankan adalah sebagai lembaga intermediasi keuangan (financial intermediary intutional) sebagaimana ditegaskan dalam pasal 1 Angka 2 Undang-Undang Nomor 10 Tahun 1998 tentang perubahan atas UndangUndang Nomor 7 Tahun 1992 yakni bahwa bank adalah badan usaha yang menghimpun dana dari masyarakat dalam bentuk simpanan dan menyalurkannya kepada masyarakat dalam bentuk kredit dan/atau bentuk-bentuk lainnya dalam rangka peningkatan taraf hidup rakyat banyak. ${ }^{3}$ Undang-Undang Nomor 21 Tahun 2008 tentang Perbankan Syariah bertujuan untuk menunjang pelaksanaan pembangunan nasional dalam rangka meningkatkan keadilan, kebersamaan, dan pemerataan kesejahteraan rakyat. Realisasi dari tujuan dimaksud terwujud dalam fungsi bank syariah dan Unit Usaha Syariah yaitu bahwa: (1) Bank Syariah dan unit usaha syariah wajib menjalankan fungsi menghimpun dan menyalurkan dana masyarakat; (2) Bank Syariah dan unit usaha syariah dapat menjalankan fungsi sosial dalam bentuk

\footnotetext{
${ }^{3}$ Khotibul Umam \& Very Antoni, Corporate Action Pembentukan Bank Syariah (Akuisisi, Konversi, dan Spin-Off), (Yogyakarta: Gadjah Mada University Press, 2018), 1.
} 
baitul mal, yaitu menerima dana yang berasal dari zakat, infak, sedekah, hibah, atau dana sosial lainnya dan menyalurkannya kepada organisasi pengelola zakat. Pelaksanaan fungsi sosial mendasarkan pada peraturan perundang-undangan terkait, yakni Undang-Undang Nomor 38 Tahun 1999 tentang Pengelolaan Zakat Hal inilah yang menunjukkan bahwa perbankan syariah berperan sebagai financial and social intermediaries institution. ${ }^{4}$

Fungsi bank syariah dalam menghimpun dana dari masyarakat dalam bentuk titipan dengan menggunakan akad alwadiah dan dalam bentuk investasi dengan menggunakan akad al-Mudharabah. AlWadiah adalah akad antara pihak pertama (masyarakat) dengan pihak kedua (bank), di mana pihak pertama menitipkan dananya kepada bank, dan pihak kedua, bank menerima titipan untuk dapat memanfaatkan titipan pihakk pertama dalam transaksi yang diperbolehkan dalam Islam. Al-Mudharabah merupakan akad antara pihak yang memiliki dana kemudian menginvestasikan dananya atau disebut juga dengan shahibul maal dengan pihak kedua atau bank yang menerima dana yang disebut juga dengan

\footnotetext{
${ }^{4}$ Abdul Ghofur Anshori: Sejarah Perkembangan Hukum Perbankan Syariah Di Indonesia Dan Implikasinya Bagi Praktik Perbankan Nasional, Jurnal Ekonomi Isalm La-Riba, 164.
}

mudharib, yang mana pihak mudharib dapat memanfaatkan dana diinvestasikan oleh shahibul maal untuk tujuan tertentu yang diperbolehkan dalam syariah Islam. ${ }^{5}$

Kegiatan menghimpun dan menyalurkan dana merupakan kegiatan pokok perbankan, sedangkan kegiatan memberikan jasa-jasa bank lainnya hanyalah merupakan pendukung dari kedua kegiatan. Pengertian menghimpun dana maksudnya adalah mengumpulkan atau mencari dana (uang) dengan cara membeli dari masyarakat luas dalam bentuk simpanan giro, tabungan dan deposito. Pembelian dana dari masyarakat ini dilakukan oleh bank dengan cara memasang berbagai strategi a gar masyarakat mau menanamkan dananya. Jenis simpanan yang dapat dipilih oleh masyarakat adalah simpanan giro, tabungan, sertifikat deposito, serta deposito berjangka di mana masing-masing jenis simpanan yang ada memiliki kelebihan dan keuntungan sendiri. Kegiatan penghimpunan dana ini sering disebut dengan istilah funding. ${ }^{6}$

$$
\text { Penghimpunan dana zakat }
$$
merupakan roda pergerakan sebuah organisasi pengelolaan zakat. Dalam pasal 1 angka 2 Undang-Undang Nomor 23 Tahun

\footnotetext{
${ }^{5}$ Ismail, Perbankan Syariah (Jakarta: Kencana, 2011), 30-31.

6 Kasmir, Manajemen Perbankan Edisi Revisi (Jakarta: Rajagrafindo Persada, 2012), 13.
} 
2011 tentang pengelolaan zakat, yang dimaksud dengan zakat adalah harta yang wajib dikeluarkan oleh seorang muslim atau badan badan usaha untuk diberikan kepada yang berhak menerimanya sesuai dengan syariat Islam. Zakat menjadi salah satu unsur dalam pokok bagi tegaknya syariat Islam. Oleh sebab itu, hukum zakat adalah wajib (fardhu) atas setiap muslim yang telah memenuhi syarat-syarat tertentu. Zakat telah diatur secara rinci berdasarkan al-Qur'an dan sunnah, zakat merupakan ibadah sekaligus merupakan amal sosial pemasyarakatan dan kemanusiaan yang dapat berkembang sesuai dengan perkembangan umat manusia. ${ }^{7}$

Zakat dalam kehidupan dan pembangunan sangat penting. Zakat Merupakan kewajiban umat Islam. Setiap umat Islam akan membayar zakat karena merupakan kewajiban. Sehingga potensi penerimaan dana zakat akan sangat besar. Dengan dana yang cukup besar tersebut, Lembaga Pengelola Zakat sangat berperan signifikan dalam kehidupan masyarakat yaitu dalam: a). Membantu mengembangkan ekonomi masyarakat miskin. b). Membuat fasilitas umum gratis seperti sekolah dan rumah sakit yang bisa memberikan layanan

\footnotetext{
${ }^{7}$ Sony Santoso \& Rinto Agustino, Zakat Sebagai Ketahanan Nasional, (Yogyakarta: Deepublish, 2018), 4.
}

secara gratis. Pendapatan dana zakat yang diterima oleh lembaga pengelola zakat. ${ }^{8}$

Salah satu bank syariah yang berada di kota Palu yang menerapkan pola syariah yaitu Bank Rakyat Indonesia Syariah (BRI Syariah) KC Wolter Monginsidi. Bank BRI syariah dapat digunakan untuk mengefektifkan penggunaan dana zakat, infak dan shadaqah dengan cara menghimpun dana zakat, infak dan shadaqah bagi kesejahteraan orang banyak.

\section{TINJAUAN PUSTAKA}

\subsection{Pengertian Bank Syariah}

Bank syariah terdiri dari dua kata, yaitu (a) bank, dan (b) syariah. Kata bank bermakna suatu lembaga keuangan yang berfungsi sebagai perantara keuangan dari dua pihak, yaitu pihak yang berkelebihan dana dan pihak yang berkekurangan dana. Kata syariah dalam versi bank syariah di Indonesia adalah aturan perjanjian berdasarkan yang dilakukan oleh pihak bank dan pihak lain yang penyimpangan dana/atau

\footnotetext{
${ }^{8}$ Moh. Khoirul Anam, Penerapan PSAK 101 Pada Laporan Dana Zakat dan Dana Kebajikan,https://www.academia.edu/33839690/Opti malisasi_Pengelolaan_Dana_Zakat_dan_Dana_Kebaji kan_pada_Bank_Syariah_Studi_Penerapan_Standar_ Akuntansi_Keuangan_PSAK_101,pdf.
} 
pembiayaan kegiatan usaha dan kegiatan lainnya sesuai dengan hukum Islam.

Penggabungan kedua kata dimaksud menjadi“bank syariah”. Bank syariah adalah suatu lembaga keuangan yang berfungsi sebagai perantara bagi pihak yang berkelebihan dana dengan pihak yang kekurangan dana untuk kegiatan usaha dan kegiatan lainnya sesuai dengan hukum Islam. selain itu, bank syariah biasa disebut Islamic banking atau interest fee banking, yaitu suatu sistem perbankan dalam pelaksanaan operasional tidak menggunakan sistem bunga (riba), spekulasi (maisir), dan ketidakpastian atau ketidakjelasan (gharar). ${ }^{9}$ Bank Syariah adalah Bank yang menjalankan kegiatan usahanya berdasarkan Prinsip Syariah dan menurut jenisnya terdiri atas Bank Umum Syariah dan Bank Pembiayaan Rakyat Syariah. Prinsip Syariah adalah prinsip hukum Islam dalam kegiatan perbankan berdasarkan fatwa yang dikeluarkan oleh lembaga yang memiliki kewenangan dalam penetapan fatwa di bidang syariah. ${ }^{10}$

\footnotetext{
${ }^{9}$ Zainuddin Ali, Hukum Perbankan Syariah (Cet.2, Jakarta: Sinar Grafika, 2010), .1

${ }^{10}$ Yenni Annor Vivin, Budi Wahono, Analisis Perbandingan Kinerja Keuangan Bank Umum Syariah Dengan Bank Umum Konvensional Di Indonesia, "E - Jurnal Riset Manajemen Prodi Manajemen Fakult as Ekonomi Unisma, 15.
}

Bank syariah merupakan Islamic Financial Institution dan lebih sekedar bank (beyond banking) yang berlandaskan ALQur'an dan hadits (tuntunan Rasulullah Saw). Yang mengacu pada prinsip muamalah, yakni sesuatu itu dibolehkan, kecuali jika ada larangannya dalam AlQur'an dan Hadis yang mengatur hubungan antar manusia terkait ekonomi, sosial, dan politik. Dalam Undang-Undang Republik Indonesia Nomor 21 Tahun 2008 tentang perbankan syariah dinyatakan bahwa bank syariah menjalankan kegiatan usaha berdasarkan prinsip syariah dan mengacu pada fatwa yang dikeluarkan oleh lembaga berwenang, dalam hal ini Dewan Syariah Nasional (DSN) di bawah Majelis Ulama Indonesia (MUI). ${ }^{11}$

Undang-undang No. 21 tahun 2008 tentang perbankan syariah disebutkan bahwa bank syariah adalah bank yang menjalankan kegiatan usahanya berdasarkan prinsip syariah. Dalam bentuk jenisnya bank syariah terdiri atas Bank Umum Syariah (BUS) dan Bank Pembiayaan Rakyat Syariah (BPRS). Makna dari bank umum syariah (BUS) adalah Bank Syariah yang dalam kegaiatannya memberikan jasa dalam lalu lintas pembayaran. Sedangkan Unit Usaha

\footnotetext{
${ }^{11}$ Ikatan Banker Indonesia, Memahami Bisnis Bank Syariah, 8.
} 
Syariah yang selanjutnya disebut UUS adalh unit kerja dari kantor pusat Bank Umum Konvensional yang berfungsi sebagai kantor induk dari kantor atau unit usaha yang melaksanakan kegiatan usaha berdasarkan prinsip Syariah, atau unit kerja di kantor cabang dari suatu Bank yang berkedudukan di luar negeri yang melaksanakan kegaiatan usaha secara konvensional yang berfungsi sebagai kantor induk dari cabang pembantu syariah dan/atau unit syariah. ${ }^{12}$

\subsection{Sejarah Bank Syariah}

Menurut sejarah, awal mula kegiatan Bank Syariah yang pertama sekali dilakukan di Pakistan dan Malaisya pada tahun 1940an. Di Kairo Mesir pada 1963 berdiri Islamic Rural Bank di desa Mit Ghamr. Bank ini beroperasi di pedesaan Mesir dan masih berskala kecil. Di Negara-negara Arab lainnya adalah Uni Emirat Arab dengan berdirinya Dubai Islamic Bank pada 1975. Kemudian di Kuwait pada 1977 berdiri Kuwait Finance House yang beroperasi tanpa bunga. Sedangkan Mesirnpada 1978 berdiri Bank Syariah yang diberi nama Faisal Islamic Bank. Langkah ini kemudian

\footnotetext{
${ }^{12}$ Sulaiman Jajuli, Produk Pendanaan Bank Syariah (Ed.,1, Cet. 1; Yogyakarta: Deepublish, 2015), 8-9.
}

diikuti oleh Islamic Internasional Bank for Invesment and Development Bank. ${ }^{13}$

Secara kelembagaan bank syariah pertama kali yang berdiri di Indonesia adalah Bank Muamalat Indonesia (BMI), kemudian baru menyusul bank-bank lain yang membuka membuka jendela usaha syariah (Islamic window) dalam menjalankan kegiatan usahanya. Melalui Islamic window ini, bank-bank konvensional dapat memberikan jasa pembiayaan syariah kepada para nasabahnya melalui produk-prod uk yang bebas dari unsure riba(usury), gharar (uncertainty), dan maysyir (speculative) dengan terlebih dahulu membentuk Unit Usaha Syariah (UUS). UUS adalah unit kerja di kantor induk dari kantor cabang syariah dan atau unit syariah.

Sedangkan secara yuridis di tataran undang-undang di mulai pada tahun 1992 dengan diundangkannya Undang-undang nomor 7 tahun 1992 tentang perbankan yang memuat ketentuan-ketentuan yang secara implisit memperbolehkan pengelolaan bank berdasarkan prinsip bagi hasil (profit and loss sharing), terutama melalui peraturan Pemerintah Nomor 72 Tahun 1992 tentang Bank Berdasarkan Prinsip Bagi Hasil. Kemudian dipertegas lagi melalui UndangUndang Nomor 10 Tahun 1998 ini secara

\footnotetext{
${ }^{13}$ Kasmir, Dasar-Dasar Perbankan, 245.
} 
tegas membedakan bank berdasarkan padaa. Larangan riba dalam berbagai bentuk pengelolaannya terdiri dari bank transaksi;

konvensional dan bank syariah, baik itu bankb. Melakukan kegiatan usaha dan perdagangan umum maupun bank perkreditan rakyat. perolehan keuntungan yang sah

Setelah di undangkannya Undang-c. Memberikan zakat. ${ }^{15}$

undang Nomor 10 tahun 1998,d. perkembangan bank syariah di Indonesia3 semakin pesat, yaitu ditandai dengan berdirinya bank syariah baru dengan sistem dual banking (dual banking system) antara lain, Bank IFI yang membuka cabang syariah pada tanggal 28 Juni 1999, Bank Syariah Mandiri yang merupakan konversi 2.3 Produk Bank Syariah

Pada dasarnya, produk yang ditawarkan oleh perbankan syariah dapat dibagi hasil kan menjadi 3 bagian besar yaitu : Produk Penyaluran Dana (financing), Produk Penghimpunan Dana (funding), dan Produk Jasa (service.)

dari Bank Susila Bakti (BSB), anak a. Penyaluran Dana perusahan Bank Mandiri, serta pendirian

Dalam menyalurkan dananya pada lima cabang baru berupa cabang syariah dari nasabah, seacar garis besar produk PT. Bank Negara Indonesia (Persero) Tbk. Pada Bulan Februari 2000, tercatat di Bank pembiayaan syariah terbagi ke dalam empat kategori yang dibedakan berdasarkan tujuan Indonesia bank-bank yang membuka cabang penggunaannnya, yaitu:

syariah, yakni Bank Niaga, Bank BTN, Bank 1. Pembiayaan dengan prinsip jual-beli Mega, bank BRI, Bank Bukopin, BPD Jabar 2. Pembiayaan dengan prinsip sewa dan BPD Aceh. ${ }^{14}$

3. Pembiayaan dengan prinsip bagi hasil

Bank syariah didirikan dengan tujuan 4. Pembiyaan dengan akad pelengkap untuk mempromosikan dan mengembankan penerapan prinsip-prinsip islam, syariah dan tradisinya ke dalam transaksi keuangan dan perbankan serta bisnis lain yang terkait. Prinsip utama yang diikuti oleh bank islam itu adalah

\footnotetext{
${ }^{14}$ Abdul Ghofur Ansori, Perbankan Syariah Di Indonesia (Yogyakarta: Gadjah Mada University Press, 2018), 30-31.
}

Pembiayaan dengan prinsip jual-beli ditunjukkan untuk memiliki barang, sedangkan yang menggunakan prinsip sewa ditujukan untuk mendapatkan jasa. Prinsip bagi hasil digunakan untuk usaha kerja sama yang ditujukan guna mendapatkan barang

${ }^{15}$ Zainul Arifin, Dasar-Dasar Manajemen Bank Syariah (Cet. 7; Jakarta: Azkia Publisher, 2009), 3 . 
dan jasa sekaligus. Pada kategori pertama dan kedua, kedua tingkat keuntungan bank ditentukan di depan dan menjadi bagian harga atas barang atau jasa yang dijual. Produk yang termasuk dalam kelompok ini adalah produk yang menggunakan prinsipa. jual-beli seperti Murabahah, Salam, dan Istishna serta produk yang menggunakan prinsip sewa, yaitu Ijarah dan IMBT. ${ }^{16}$

Sedangkan pada kategori ketiga, tingkat keuntungan bank ditentukan dari besarnya keuntungan usaha sesuai dengan prinsip begi hasil . Pada produk bagi hasil keuntungan usaha ditentukan oleh nisbah bagi hasil yang disepakati dimuka. Produk perbankan yang termasuk ke dalam kelompok ini adalah Musyarakah dan Mudharabah. Sedangkan pembiayaan dengan akad pelengkap ditujukan untuk memperlancar pembiayaan dengan menggunakan tiga prisip diatas. Kita akan membahas masing-masing produk ini dengan lebih rinci pada uraian berikut.

\section{A. Prinsip Jual Beli (Ba'i)}

Prinsip jual-beli dilaksanakan sehubungan dengan adanya perpindahan kepemilikkan barang atau benda (transfer of property). Tingkat keuntungan bank ditentukan di depan dan menjadi bagian

\footnotetext{
${ }^{16}$ Adiwarman A. Karim, Bank Islam: Analisis Fiqih dan Keuangan (Ed. 8; Jakarta: Rajawali Pers, 2011), 96.
}

harga atas barang yang dijual. Transaksi jual-beli dapat dibedakan berdasarkan bentuk pembayarannya dan waktu penyerahan barangnya, yakni sebagai berikut :

Pembiayaan Murabahah

\section{Murabahah (al-bai' bi tsaman ajil)} lebih dikenal sebagai murabahah saja. Murabahah, yang berasal dari kata ribhu (keuntungan), adalah transaksi jual-beli dimana bank menyebut jumlah keuntungannya. Bank bertindak sebagai penjual, sementara nasabah sebagai pembeli. Harga jual adalah harga beli bank dari pemasok ditambah keuntungan (marjin). ${ }^{17}$

Kedua belah pihak harus menyepakati harga jual dan jangka waktu pemabayara. Harga jual dicantumkan dalam akad jual beli dan jika telah disepakati tidak dapat berubah salam berlakunya akad. Dalam perbankan, murabahah selalu dilakukan dengan cara pembayaran cicilan (bi tsaman ajil, atau muajjal). Dalam transaksi ini barang diserahkan segara setelah akad, sementara pembayaran dilakukan secara tangguh atau cicilan. ${ }^{18}$

b. Pembiayaan Salam

Salam adalah transkasi jual beli dimana barang yang diperjualbelikan belum

\footnotetext{
${ }^{17}$ Ibid., 97.

${ }^{18}$ Ibid, 98.
} 
ada. Oleh karena itu, barang diserahkan secara tangguh sementara pembayaran dilakukan tunai. Bank bertindak sebagai pembeli, sementara nasabah sebagai penjual. Sekilas transaksi ini mirip jual beli ijon, namun dalam transaksi ini kuantitas, kualitas, harga, dan waktu penyerahan barang harus ditentukan secara pasti.

c. Pembiayaan Istishna,

\section{Pembiayaan Musyarakah}

Produk istishna' menyerupai produk salam, tetapi dalam istishna' pembayarannya dapat dilakukan oleh bank dalam beberapa kali (termini) pembayaraan. Skim Istishan' dalam Bank Syariah umumnya diaplikasikan pada pembiayaan manufaktur dan konstruksi. Ketentukan umum Pembiayaan istishan' adalah spesifikasi barang pesanan harus jelas seperti jenis, macam ukuran2. mutu dan jumlahnya . Harga jual yang telah disepakati dicuntamkan dalam akad istishna' dan tidak boleh berubah selama berlakunya akad. Jika terjadi perubahan dari kriteria pesanan dan terjadi perubahan harga setelah akad ditandatangani, seluruh biaya tambahan tetap ditanggung nasabah.

\section{B. Prinsip Sewa (Ijarah)}

Transaksi Ijarah dilandasi adanya perpindahan manfaat. Jadi pada dasarnya prinsip ijarah sama saja dengan prinsip jual beli, tapi perbedaannya terletak pada objek transaksinya . Bila pada jual-beli objek transaksinya adalah barang pada ijarah objek transaksinya adalah jasa.

\section{Prinsip Bagi Hasil (Syirkah)}

Produk pembiayaan syariah yang didasarkan atas prinsp bagi hasil adalah sebagai berikut.

Bentuk umum dari usaha bagi hasil adalah musyarakah (syirkah atau syarikah). Transaksi musyrakah dilandasi ada nya keinginan para pihak yang berkerja sama untuk meningkatkan nilai asset yang mereka miliki secara bersama-sama memadukan seluruh bentuk sumber daya baik yang berwujud maupun tidak berwujud. ${ }^{19}$

\section{Pembiayaan Mudharabah}

Mudharabah adalah bentuk kerja sama antara dua atau lebih pihak di mana pemilik modal (shahib al-maal) mempercayakan sejumlah modal kepada pengelola (mudharib) dengan suatu perjanjian pembagian keuntungan. Bentuk ini menegaskan kerja sama dalam paduan kontribusi $100 \%$ modal kas dari shahib almaal dan keahlian dari mudharib. Transaksi jenis ini tidak mensyarakat adanya wakil shahib al-maal dalam manajemen proyek. Sebagai orang kepercayaan, mudharib harus

${ }^{19}$ Ibid, 99-102. 
bertindak hati-hati dan bertanggung jawab untuk setiap kerugian yang terjadi akibat kelalaian. Sedangkan sebagai wakil shahib al- maal dia diharapkan untuk mengelola modal dengan cara tertentu untuk menciptakan laba optimal.

\section{Akad Pelengkap}

\section{Hiwalah (Alih Utang - Piutang)}

Hiwalah adalah untuk membantu supplier mendapatkan modal tunai agar dapat melanjutkan produksinya. Bank mendapatkan ganti biaya atas jasa pemindahan piutang. Untuk mengantisipasi risiko kerugian yang akan timbul, bank perlu melakukan penelitian atas kemampuan pihak yang berutang dan kebenaran transaksi antara yang memindahkan piutang dengan yang berutang . Katakanlah seorang supplier bahan bangunan menjual barang nya kepada pemilik proyek yang akan dibayar dua bulan kemudian. Karena kebutuhan supplier akan likuiditas, maka ia meminta bank untuk mengambil alih piutangnya. Bank akan3. menerima pembayaran dari pemilik proyek. $^{20}$

\section{Rahn (Gadai)}

Tujuan akad Rahn adalah untuk memberikan jaminan pembayaran kembali kepada bank dalam memberikan pembiayaan.

Barang yang digadaikan wajib memenuhi kriteria: Milik nasabah sendiri, jelas ukuran, sifat, dan nilainya ditentukan berdasarkan nilai riil pasar. Dapat dikuasai namun tidak boleh dimanfaatkan oleh bank. ${ }^{21}$

Atas izin bank, nasabah dapat menggunakan barang tertentu yang digadaikan dengan tidak mengurangi nilai dan merusak barang yang digadaikan. Apabila barang yang digadaikan rusak atau cacat, nasabah harus bertanggung jawab. Apabila nasabah wanprestasi, bank dapat melakukan penjualan barang yang digadaikan atas perintah hakim. Nasabah mempunyai hak untuk menjual barang tersebut dengan seizing bank. Apabila hasil penjualan melebihi kewajibannya, kelebihan tersebut menjadi milik nasabah. Dalam hal hasil penjualan tersebut lebih kecil dari kewajibannya, maka nasabah harus menutupi kekurangannya.

\section{Qardh}

Qardh adalah pinjaman uang. Apabila qardh dalam perbankan biasanya dalam empat hal, yaitu :

a. Sebagai pinjaman talangan haji, di mana nasabah calon haji diberikan pinjaman talangan untuk memenuhi syarat 
penyetoran biaya perjalanan haji. penyelesain L/C (settlement L/C ) dapat Nasabah akan melunasinya sebelum dilakukan deangan pembiayaan murabahah, keberangkatannya ke haji.

b. Sebagai pinjaman tunai (cash advanced) salam, ijarah, mudharabah, atau musyarakah.

dari produk kartu kredit syariah, di mana5. Kafalah (Garansi Bank)

nasabah diberi keleluasaan untuk menarik

Garansi bank dapat diberikan dengan uang tunai milik bank melalui ATM. Nasabah akan mengembalikannya sesuai waktu yang ditentukan.

tujuan untuk menjamin pembayaran suatu kewajiban pembayaran. Bank dapat mensyarakatkan nasabah untuk

c. Sebagai Pinjaman kepada pengurus kecil, di mana menurut perhitungan bank akan memberatkan si pengusaha bila diberikan pembiayaan dengan skema jual beli, ijarah,atau bagi hasil.

menempatkan sejumlah dana untuk menempatkan sejumlah dana untuk fasilitas ini sebagai rahn. Bank dapat pula menerima dana tersebut dengan prinsip wadi'ah. Untuk jasa - jasa ini, bank mendapatkan pengganti

d. Sebagai pinjaman kepada pengurus bank, di mana bank menyediakan fasilitas ini untuk memastikan terpenuhinya kebutuhan pengurus bank. Pengurus bank akan mengembalikan dana pinjaman itu secara cicilan melalui pemotongan gajinya. biaya atas jasa yang diberikan. ${ }^{22}$

\subsection{Pengertian Zakat, Infak dan Sadaqah}

\section{Zakat}

Ditinjau dari segi bahasa, kata zakat

\section{Wakalah (Perwakilan)}

Wakalah dalam aplikasi perbankan terjadi apabila nasabah memberikan kuasa kepada bank untuk mewakili dirinya melakukan pekerjaan jasa tertentu, seperti pembukaan L/C , inkaso dan transfer uang. Bank dan nasabah yang dicantumkan dalam akad pemberian kuasa harus cakap hukum. Khusus untuk pembukaan L/C , apabila dana nasabah ternayata tidak cukup, maka mempunyai beberapa arti, yaitu al-barakatu' keberkahan", al-namaa 'pertumbuhan dan perkembangan', ath-thaharatu 'kesucian', dan ash- salahatu ' keberesan. Sedangkan secara istilah, meskipun para ulama mengemukakannya dengan redaksi yang agak berbeda antara satu dengan yang lainnya, akan tetapi harta dengan pada prisipnya sama, yaitu bahwa zakat itu adalah

\footnotetext{
${ }^{22}$ Ibid, 106-107.
} 
bagian dari harta dengan persyaratan tertentu, yang Allah SWT mewajibkan kepada pemiliknya, untuk diserahkan kepada yang berhak menerimanya, dengan persyaratan tertentu. $^{23}$

Zakat dari segi fiqh berarti sejumlah harta tertentu yang diwajibkan Allah untuk diserahkan kepada orang-orang. Harta benda yang dikeluarjkan ini disebut zakat karena ia menjadi penyebab harta dapat berkembang. zakat merupakan bagian dari kewajiban seorang Muslim. ${ }^{24}$ Didalam kitab al-Hawi, al-Mawardi mendefinisikan zakat dengan nama pengambilan tertentu dari harta yang tertentu, menurut sifat-sifat tertentu, dan untuk diberikan kepada golongan tertentu. ${ }^{25}$ Imam asy Syarkhasyi al Hanafi dalam kitabnya al mabsuth mengatakan bahwa dari segi bahasa zakat adalah tumbuh dan bertambah. Disebut zakat karena sesungguhnya ia menjadi sebab bertambahnya harta di mana Allah ta'ala

${ }^{23}$ Didin Hafidhuddin, Zakat Dalam Perekonomian Modern (Jakarta: Gema Insane, 2002), 7.

${ }^{24}$ Lilik Ummi Kalsum, Abd. Moqsith, Tafsir Ayat-Ayat Ahkam (Jakarta: UIN Press, 2015), 37.

${ }^{25}$ Ahmad Hadi Yasin, Panduan Zakat Dompet Dhuafa, 10 https://www.dompetdhuafa.org/uploads/media/PAND UAN-ZAKAT-1433-web.pdf. diakses 15 April 2019. menggantikannya di dunia dan pahala di akhirat. ${ }^{26}$

Berdasarkan pengertian secara bahasa maupun istilah tersebut dapat disimpulkan bahwa zakat mamiliki empat sifat. Pertama, zakat memberikan keberkahan bagi yang yang mengeluarkan zakat (muzakki). Kedua, tumbuh dan berkembang. dari harta zakat yang dioptimalkan akan menumbuh kembangkan potensi-potensi baik dari para muzakki maupun dari masyarakat secara umum. Hal ini disebabkan keberkahan yang dikaruniakan Allah Swt. atas harta yang bersih. Ketiga, adalah kesucian. Dengan zakat, Allah Swt. mensucikan baik harta maupun jiwa seorang manusia. Keempat, beres atau keberesan. Sifat ini mengandung pengertian bahwa harta yang selalu di zakati senantiasa terjauh dari permasalahan baik di dunia dan di akhirat. ${ }^{27}$

Zakat merupakan pungutan wajib atas individu yang memiliki harta wajib zakat yang melebihi nishab (muzakki), dan didistribusikan kepada delapan Golongan penerima zakat (mustahik), yaitu fakir,

\footnotetext{
${ }^{26}$ Gus Arifin, Dalil-Dalil dan Keutamaan, Zakat, Infak Sedekah, Menurut Fiqh 4 Mazhab (Jakarta: Elex Media Komputindo,2011), 4.

${ }^{27}$ Setiawan Badi Utomo, Metode Praktik Penetapan Nisab Zakat (Bandung: PT Mizan Pustaka, 2009), 31-32.
} 
miskin, fi sabilillah, ibnussabil, amil, gharimin, hamba sahaya, dan muallaf.

Penerapan sistem zakat akan mempunyai berbagai implikasi di berbagai segi kehidupan, antara lain:

1) Memenuhi kebutuhan masyarakat yang kekurangan.

2) Memperkecil jurang kesenjangan ekonomi.

3) Menekan jumlah permasalahan sosial, kriminalitas, pelacuran, gelandangan, pengemis dan lain-lain.

4) Menjaga kemampuan beli masyarakat agar dapat memelihara sector usaha. Dengan kata lain zakat menjaga konsumsi masyarakat pada tingkat yang minimal sehingga perekonomian dapat terus berjalan.

5) Mendorong masyarakat untuk berinvestasi, tidak menumpuk harta. ${ }^{28}$

\section{Infaq}

Infaq dalam bahasa arab berasal dari kata nafaqa (نققة) yang berarti pengeluaran atau pembelanjaan. ${ }^{29}$ Secara bahasa kata infaq berarti kosong. Baik yang disebabkan oleh kematian, pemberian, penjualan dan lain-lain. Penggunaan kata ini diibaratkan

${ }^{28}$ Ascarya, Akad dan Produk Bank Syariah (Ed, 1-3; Jakarta: Rajawali Pers, 2011), 8.

${ }^{29}$ Atabik Ali. Ahmad Zuhdi Muhdlor, Kamus Kontemporer Arab-Indonesia (Cet.9; Yogyakarta: Multi Karya Grafika, 2004), 1934. dengan sebuah bangunan bata. Apabila salah satu bata tersebut di ambil maka akan terlihat kosong atau ada yang hilang. Dengan demikian, pemaknaan infaq masih terkesan umum tanpa batasan objek ataupun tujuannya. Sedangkan secara istilah kata mengeluarkan atau memberikan segala nikmat atau rizki kepada orang lain baik berupa harta ataupun yang lain sehingga yang asalnya ada menjadi hilang kepada siapapun untuk tujuan-tujuan yang lain. ${ }^{30}$ Infaq, menurut istilah para ulama diartikan sebagai perbuatan atau sesuatu yang diberikan oleh seseorang untuk menutupi kebutuhan orang lain, baik berupa makanan, minuman, dan sebagainya juga mendermakan atau memberikan sesuatu kepada orang lain berdasarkan rasa ikhlas dan karena Allah SWT semata. Dalam pandangan syariat islam orang yang berinfaq akan memperoleh keberuntungan yang berlipat ganda baik di dunia maupun di akhirat. Ada tiga Golongan yang diwajibkan mengeluarkan infaqnya adalah sebagai berikut:

1. Mereka yang sedang dalam kesimpitan juga diwajibkan untuk mengeluarkan infaq, bagi Golongan ini berlaku infaq minimal $10 \%$ dari penghasilan. Ahkam, 32.

${ }^{30}$ Kalsum, Abd. Moqsith, Tafsir Ayat-Ayat 
2. Mereka yang dalam keadaan mampu atau dalam kelapangan, berlaku minimal 20$35 \%$ dari penghasilan.

3. Mereka yang berlebih, terkena infaq diatas $50 \%$ sampai dengan $100 \% .^{31}$

\section{Shadaqah}

Sedekah berasal dari kata shadaqah yang berarti 'benar'. Orang yang suka bersedekah adalah orang yang benar imannya. Menurut terminologi syariat, pengertian sedekah sama dengan pengertian infak, termasuk juga hukum dan ketentuanketentuannya. Hanya saja, jika infak berkaitan dengan materi, sedekah memiliki arti lebih luas, menyangkut hal yang bersifat non materiil. ${ }^{32}$

Sedekah adalah pemberian sesuatu dari seorang muslim kepada yang berhak menerimanya secara ikhlas dan sukarela tanpa dibatasi oleh waktu dan jumlah tertentu denga mengharapkan ridha Allah dan pahala semata. Menurut Al-Jurjani, mengartikan sedekah sebagai pemberian seseorang secara ikhlas kepada yang berhak menerimanya yang diiringi oleh pemberian pahala dari Allah SWT. Berdasarkan

${ }^{31}$ Elsi Kartika Sari, Pengantar Hukum Zakat dan Wakaf(Jakarta: PT Grasindo, 2006), 7.

${ }^{32}$ Didin Hafinuddin, Panduan Praktik Tentang Zakat, Infak dan Sedekah (Cet. 1; Jakarta: Gema Insani, 1998), 15. pengertian ini, infak adalah (pemberian atau sumbangan) harta untuk kebaikan termasuk dalam kategori sedekah.

\section{METODE PENELITIAN}

Penelitian ini menggunakan jenis penelitian kualitatif. Menurut Denzin \& Lincoln menyatakan bahwa penelitian kualitatif adalah penelitian yang menggunakan latar alamiah dengan maksud menafsirkan fenomena yang terjadi dan dilakukan dengan jalan melibatkan berbagai metode yang ada. ${ }^{33}$ Sedangkan menurut Imron Arifin mengemukakan bahwa penelitian kualitatif yaitu penelitian yang bersifat fleksibel, terbuka dan dapat dikondisikan berdasarkan lapangan penelitian. $^{34}$

Penelitian Kualitatif adalah penelitian yang bermaksud untuk memahami fenomena tentang apa yang dialami oleh subjek penelitian misalnya perilaku, persepsi, motivasi, tindakan, secara holistik dan dengan cara deskripsi dalam bentuk kata kata dan bahasa, pada suatu konteks khusus yang alamiah dan dengan memanfaatkan

\footnotetext{
${ }^{33}$ Albi Anggito \& Johan Setiawan, Metode Penelitian Kualitatif (Sukabumi: CV Jejak, Oktober 2018 ), 7.

${ }^{34}$ Imron Arifin, Penelitian Kualitatif dalam Ilmu-Ilmu Sosial dan Keagamaan (Cet, III; Malang: Kalimasada Press, 1996), 40
} 
berbagai metode alamiah. ${ }^{35}$ Penelitian ini bersifat kualitatif deskripstif yaitu menggambarkan proses penghimpunan dana zakat, infaq dan shadaqah.

Lokasi penelitian di Bank BRI Syariah KC Wortel Monginsidi di Kota Palu, penentuan lokasi penelitian ini berdasarkan atas fokus penelitian yang akan dilakukan. Fokus lokasi yang dimaksud adalah atas pertimbangan kemudahan memperoleh informasi yang dibutuhkan dalam penelitian ini dengan berbagai pertimbangan. Pertama, bank BRI Syariah dipilih sebagai lokasi penelitian karena merupakan salah tempat penyaluran dana zakat, infaq dan sadaqah. Kedua, akses dan informasi mengenai data penelitian yang mudah didapatkan oleh peneliti.

Data dikumpul melalui observasi,a. wawancara mendalam, dan dari dokumen yang ada. Wawancara dilakukan dengan Manager Marketing dan beberapa karyawan di Bank BRI Syariah. Selanjutnya data dianalisi dengan melakukan reduksi data, melalukan presentasi data, dan akhirnya analisis berdasarkan tema-tema yang muncul dalam wawancar.

\section{HASIL DAN PEMBAHASAN}

${ }^{35}$ Lexy J. Moeloeng, Metodologi Penelitian Kualitatif edisi revisi (Bandung: PT Remaja Rosdakarya, 2005), 6.
4.1 Praktik Penghimpunan Dana ZIS di Bank BRI Syariah

Praktik penghimpuanan Dana ZIS merupakan salah satu produk tabungan yang disediakan oleh Bank BRI Syariah dan sudah sesuai dengan peraturan yang ada di dalam. Penghimpunan dana ZIS dapat diartikan sebagai kegiatan menghimpun dana dan sumber daya lainnya dari masyarakat (baik individu, kelompok, organisasi, perusahaan ataupun pemerintahan) yang akan digunakan untuk membiayai program kegiatan operasional lembaga yang ada pada akhirnya adalah untuk mencapai misi dan tujuan dari lembaga tersebut. Adapun langkah praktik penghimpunan dan ZIS di BRI Syariah yaitu:

Mekanisme Penyetoran Dana ZIS pada BRI Syariah

Praktik penghimpunan Dana ZIS di BRI Syariah yaitu dengan cara melakukan pembukaan rekening tabungan, sesuai dengan pilihan nasabah yang ingin melakukan zakat, infak dan sedekah. Cara nasabah untuk melakukan penghimpunan dana ZIS berdasarkan hasil wawancara bersama Agung Prastia dan nasabah adalah:

$$
\begin{aligned}
& \text { Penghimpunan Dana yaitu } \\
& \text { menggumpulkan atau menerima } \\
& \text { tabungan dari nasabah secara manual } \\
& \text { yang dikumpulkan dan dihimpunkan } \\
& \text { dengan cara yang pertama nasabah }
\end{aligned}
$$


harus membuka rekening terlebih1. Mengisi formulir pendaftaran sesuai dahulu dengan melakukan pengisian formulir sesuai dengan identitas nasabah seperti, KTP. Adapun peran BRI Syariah dalam melakukan praktik penghimpunan dana ZIS $^{2}$ untuk menarik nasabah dengan cara kerja sama diberbagai instansi seperti, IAIN dan kegiatan di pemerintahan daerah. (Bank3. membuka open table dikegiatan tersebut dengan melakukan penawaran produk dan menyebarkan brosur untuk mengajak masyarakat membuka rekening/tabungan). ${ }^{36}$

Hal ini di ungkapkan oleh nasabah bahwa ketika pertama kali melakukan pembukaan rekening/tabungan, dari customer service diberikan pengisian formulir atau pendaftaran untuk awal membuka rekening dan memberikan informasi terkait dana ZIS yang mana nasabah dengan bebas memilih untuk ikut dalam produk dana ZIS atau tidak. Setelah pengisian formulir tersebut nasabah langsung menyetorkan kembali dengan minimal uang yang distor sebesar Rp. 100.000 ribu. Pihak juga menjelaskan terkait adanya pemotong dengan gaji. ${ }^{37}$

Penjelasan dari Agung Prastia dan nasabah penulis dapat simpulkan bahwa Praktik penghimpunan Dana ZIS di Bank BRI Syariah Langkah nya sebagai berikut:

\footnotetext{
${ }^{36}$ Agung, marketing Relationship officer, wawancara pada tanggal 4 Juli 2019

${ }^{37}$ Mutmainnah, Nasabah Bank BRI Syariah, wawancara pada tanggal 10 Juli 2019.
}

identitas (KTP) dengan lengkap, jujur, dan akurat.

Mengembalikan formulir ke costumer servicedan memberikan uang penyetoran sebesar Rp. 100.000.

BRI Syariah Memiliki peranan penting dalam melakukan penawaran produk kepada nasabah dengan cara kerja sama diberbagai instansi.

Ditambahkan pula oleh Ainun Abdullah bahwa selain melakukan pembukaan rekening dengan cara mendaftar langkah selanjutanya yaitu menyetor uang saldo awal yang berjumlah minimal Rp 100.000,- ribu. Pada saaat nasabah sudah melakukan penyetoran awal, nasabah akan diberikan pilihan oleh customer service untuk melakukan Check list bila ingin berzakat dengan potongan zakat 2,5\%. Akan tetapi Jika nasabah tidak ingin membuka produk ZIS tidak ada paksaan dari bank. adapun ketika nasabah memiliki tabungan dengan jumlah setoran awal Rp 100.000 ribu, maka $1 \%$ dari 100 ribu yaitu 100 rupiah, berarti $2,5 \%=250$ rupiah. ${ }^{38}$

Hal ini sesuai dengan pernyataan Reza Tabanal bahwa selain zakat, infak dan shodoqah yang mana dimasukkan dalam system pembayaran auto debet misalnya nya

${ }^{38}$ Ainun, Costumer Service, wawancara pada tanggal 4 Juli 2019 
dari gaji perbulan nasabah. Ketika nasabah sudah setuju dengan sistem pembayaran auto debet maka perbulannya akan terjadi pemotongan secara otomatis dan uang tersebut akan tersalurkan langsung ke lembaga BAZNAS. ${ }^{39}$

Hal yang senada pula diungkapkan oleh imam bahwa untuk penghimpunan infak dan sedekah, dana tersebut otomatis secara langsung semuanya akan masuk kekantor pusat dengan cara structural, dan bank BRI Syariah tidak mengambil sedikit pun dana tersebut akan langsung tersalurkan masuk kelembaga BAZNAS., sedangkan untuk nasabah yang sudah memiliki tabungan dan ingin berinfak dan bersedekah, akan memiliki ATM, dimana ATM menjadi salah satu fasilitas dari bank untuk mempermudah nasabah dalam melakukan infak dan shadaqah. Selain ATM, Mobile Banking merupakan salah satu fasilitas yang diberikan bank kepada nasabah untuk melakukan praktik penghimpunan dana ZIS. $^{40}$

Berdasarkan hasil wawancara Ainun,Reza, dan Imam dapat disimpulkan bahwa: Dibank BRI Syariah pada saat nasabah membuka rekening, customor

\footnotetext{
${ }^{39}$ Reza Tabanal, Manager Marketing, Wawancara Pada Tanggal 7 Juli 2019

${ }^{40}$ Imam, Marketing Ao Task Force, Wawancara Pada Tanggal 3 Juli 2019
}

service memberikan informasi terkait untuk memilih/membuka zakat, infak, shadaqah. Nasabah yang ingin membuka rekening dan memilih untuk zakat, infak, shadaqah secara langsung akan terjadi pemotongan, sedangkan pada nasabah yang tidak memilih untuk berzakat, infak, shadaqah pihak bank tidak memaksakannya. Bank BRI Syariah memiliki peran yang sangat penting dalam produk dana ZIS tersebut dengan menyediakan beberapa fasilitas terkait produk tersebut agar nasabah dengan mudah mengaksesnya melalui ATM dan via Mobile Banking.

\subsection{Faktor Pendukung dan Penghambat} Pengumpulan Dana ZIS

Faktor pendukung adalah hal-hal yang mempengaruhi sesuatu menjadi berkembang, memajukan, menambah dan menjadi lebih dari sebelumnya. Sedangkan Faktor penghambat adalah sesuatu yang dapat menghalangi kemajuan atau pencapaian suatu hal.

a. Faktor Pendukung

Berdasarkan hasil wawancara dengan Agung Prasetia, ada sejumlah factor yang mendukung terlaksananya pengumpulan zakat, infaq dan sadaqah di Bank BRI Syariah yang antara lain yaitu:

faktor pendukung nya salah satunya dari pemerintah misalnya dari ojk 
sendiri menerapkan, misalnya contoh nya kebijakan menabung untuk dengan setoran ringan. Misalnya pemerintah pusat kebijakan nya PNS yang disatu instansi bisa memiliki gaji nya itu disalurkan melalui bank, ada 2 pilihan bank konvensional dan syariah .jadi bank syariah sudah bisa menjadi apa nya suatu pilihan nya nasabah kalang-kalang PNS. Untuk memilih Bri syariah sebagai penyedia atau penyalur gajinya itu salah satu aturan pemerintah kementrian keuangan. ${ }^{41}$

\section{Faktor Internel}

1. Komitmen dari BRI Syariah yang telah menwujudkan dalam menyediakan bentuk jasa layanan untuk zakat, infak, shodoqah.

2. Layanan yang di sediakan BRI Syariah sudah sangat mendukung yakni sebagai faktor pendukung yaitu, media masa, Sosial media

3. Facebbok,Instagram, dan Twitter, dan spanduk - spanduk. Selain dengan cara yang disebutkan diatas tadi Bank BRI Syariah menyediakan Fasilitas kepada nasabah dengan Mobile Banking yang memberikan kemudahan pada nasabah untuk melakukan zakat,infak, shodoqah secara langsung.

\section{Faktor eksternal}

1. OJK yang sangat memberikan dukungan penuh terhadap kebijakan pemerintah keuangan yang sudah memilih BRI Syariah

\footnotetext{
${ }^{41}$ Agung Prasitia, Wawancara 4 Juli 2019
}

sebagai salah salah instansi yang sudah bisa memiliki gajinya dihimpun melalui Bank Syariah tersebut.

b. Faktor Penghambat

Kemudian sejumlah factor penghambat juga terdapat dalam proses pengumpulan ZIS, faktor penghambat tersebut ada yang berasal dari internal dan external. Berikut ini penjelasan penghambat dari internal dan external.

1. Internal

Dana ialah sebagai salah satu penghimpunan Namun di Bank BRI Syariah masih mengalami terkendala dana dalam memasarkan produk, dan untuk melakukan promosi-promosi membutuhkan biaya yang sangat besar, seperti membuat spanduk dan memasang iklan - iklan di TV.

\section{Eksternal}

Pemahaman edukasi dari masyarakat masih kurang terhadap Bank BRI Syariah,masih sangat sedikit masyarakat yang tahu tentang - tentang produk produk di Bank tersebut.

Berdasarkan hasil wawancara bersama Ainun Abdullah tentang faktor pendukung yaitu:

Ainun Abdullah menambahkan kalau untuk pendukung nya yaitu dari sosial media Facebook, Ig, Twitter dan mobile banking, media massa, dan Channel BRI. Kalau dipembukaan rekening itu, tapi kebanyakkan kita ngak kasih zakat, 
tabungan faedah, jadi kalau nasabah mau berzakat ambil 2,5\% dari tabungan nya contoh nya tabungan ada 100 ribu , 1 \% nya itu kan 100 rupiah, berarti $2,5 \%=250$ rupiah . Jadi apa namanya kalau seandainya nasabah mau zakat minimal 2,5\% = berarti $1,5 \%$. Tapi Selama sya jadi cs belum pernah saya kasih begituh, karna bgini dek. Saya jelaskan . kalau bank syariah ada system bagi hasil ,tergantung berapa labanya bank perbulan, jadi sebetulnya kita kan kalau faedah harusnya tidak ada wadiah betul -betul titipan berarti rill uang nya ada didalam, tapi kalau kita di sini tidak dek kalau tinggi laba nya bank pasti akan kita kasih bagi hasil. ${ }^{42}$

Dalam table 2 berikut ini disimpulkan faktor pendukung dan penghambat.

Tabel 2. Faktor Pendukung dan Penghambat

\begin{tabular}{|c|c|c|}
\hline No & $\begin{array}{c}\text { Faktor } \\
\text { pendukung }\end{array}$ & Faktor penghambat \\
\hline 1. & $\begin{array}{l}\text { Sosial media } \\
\text { IG, FB dan } \\
\text { Twitter }\end{array}$ & $\begin{array}{c}\text { Pemahaman } \\
\text { edukasi masyarakat } \\
\text { yang masih kurang }\end{array}$ \\
\hline 2. & $\begin{array}{l}\text { Mobile } \\
\text { Banking }\end{array}$ & $\begin{array}{l}\quad \text { Promosi } \\
\text { promosi yang } \\
\text { membutuhkan }\end{array}$ \\
\hline 3. & $\begin{array}{l}\text { Media Masa } \\
\text { Channel }\end{array}$ & dana. \\
\hline & $\begin{array}{l}\text { BRI } \\
\quad \text { Spanduk- } \\
\text { spanduk }\end{array}$ & \begin{tabular}{l}
\multicolumn{2}{c}{ Terkendala } \\
dana dalam \\
memasarkan
\end{tabular} \\
\hline 4. & \begin{tabular}{l}
\multicolumn{1}{c}{ Kebijakan } \\
pemerintah \\
untuk \\
menabung \\
dengan setoran \\
tunai.
\end{tabular} & $\begin{array}{l}\text { produk. Misalnya } \\
\text { membuat spanduk, } \\
\text { dan iklan-iklan di } \\
\text { TV. }\end{array}$ \\
\hline
\end{tabular}

${ }^{42}$ Ainun Abdullah, Wawancara 4 Juli 2019

\section{Kesimpulan}

Dari hasil penelitian yang didapat peneliti berdasarkan hasil penelitian lapangan, dapat disimpulkan bahwa praktik penghimpunan dana Zakat, Infaq dan Shadaqah di Bank BRI Syariah Kota Palu adalah sudah sesuai dengan aturan yang ada dimana dengan menawarkan produk. Produk yang di tawarkan adalah mengajak nasabah membuka rekening tabungan dan CS menawarkan kepada nasabah yang ingin menyalurkan zakat, infaq dan shadaqah dengan pemotongan debet perbulan. Praktik penghimpunan lainnya yaitu dengan menyebarkan brosur, sosialisasi penggunaan mobile banking dalam menyalurkan dana ZIS.

Faktor pendukung penghimpunan dana Zakat, Infaq dan Shadaqah di Bank BRI Syariah adalah sosialisasi melalui sosial media, IG, FB, Twiter, mobile banking, media masa, channel BRI, spanduk-spanduk dan kebijakan pemerintah untuk menabung dengan setoran tunai. Sedangkan faktor penghambat atau kendala-kendala dalam penghimpunan dan Zakat, Infaq dan Shadaqah adalah pemahaman edukasi masyarakat yang masih kurang, promosipromosi yang membutuhkan dana dan kendala lainnya adalah terkendala dana 
dalam memasarkan produk. Misalnya membuat spanduk dan iklan-iklan TV.

\section{Daftar Pustaka}

Al-Qur'an dan Terjemahnya Ascarya. Akad dan Produk Bank Syariah Ed. 1-3; Jakarta: Rajawali Pers, 2011.

Ahmadi, Ruslan. Metodologi Penelitian Kualitatif Yogyakarta: Ar-Ruzz Media, 2014.

Ali, Zainuddin. Hukum Perbankan Syariah, Cet.2, Jakarta: Sinar Grafika, 2010.

Anggito, Albi \& Setiawan Johan. Metode Penelitian Kualitatif, Sukabumi; CV Jejak, Oktober 2018.

Anshori, Abdul Ghofur: Sejarah Perkembangan Hukum Perbankan Syariah Di Indonesia Dan Implikasinya Bagi Praktik Perbankan Nasional, Jurnal Ekonomi Isalm LaRiba.

- Perbankan Syariah Di

Indonesia, Yogyakarta: Gadjah Mada University Press, 2018.

Arifin, Gus. Dalil-Dalil dan Keutamaan, Zakat, Infak Sedekah, Menurut Figh 4 Mazhab Jakarta: Elex Media Komputindo, 2011.

Arifin, Zainul. Dasar-Dasar Manajemen Bank Syariah, Jakarta: Azkia Publisher, 2009.

Hafidhuddin, Didin. Zakat Dalam Perekonomian Modern, Jakarta: Gema Insane, 2002. Panduan Praktik Tentang Zakat, Infak dan Sedekah Cet, 1, Jakarta: Gema Insani, 1998.

Hasbiyallah. Fiqh dan Ushul Fiqh:Metode Istinbath dan Istidlal Bandung, PT Remaja Rosdakarya, 2013.

Idrus, Muhammad. Metode Penelitian Ilmu Sosial, Jakarta: Penerbit Erlangga, 2009.
Ikatan Banker Indonesia, Memahami Bisnis Syariah, Jakarta: PT Gramedia Pustaka Utama, 2014.

Irawan, Andri. Rodliyah, Nunung. Wardani, Yulia Kusuma.

Penghimpunan Dana Dengan Akad Mudharabahpada Bank Rakyat Indonesia Syariah, Pactum Law Journal 1, No. 3 (2018).

Ismail. Perbankan Syariah, Jakarta:

Kencana, 2011.

Jajuli, Sulaiman. Produk Pendanaan Bank Syariah, Ed.,1, Cet. 1; Yogyakarta: Deepublish, 2015.

Kalsum, Lilik Ummi. Moqsith Abd., Tafsir Ayat-Ayat Ahkam, Jakarta: UIN Press, 2015.

Karim, Adiwarman A. Bank Islam: Analisis Fiqih dan Keuangan, Ed. 8, Jakarta: Rajawali Pers, 2011.

Kasmir, Manajemen Perbankan Edisi Revisi, Jakarta: Rajagrafindo Persada, 2012.

Khasanah, Yumrohatul. Mekanisme Penghimpunan Dan Pendistribusian Dana Zakat, Infaq dan Shadakah (ZIS) Untuk Anak Yatim Piatu Pada Devisi Sosial Baitul Maal Di KJKS BMT Muamalat Limpung, Skripsi tidak diterbitkan (Semarang: Jurusan Ekonomi Islam Fakultas Ekonomi dan Bisnis Islam UIN Walisongo, 2015).

Mardani, Aspek Hukum Lembaga Keuangan Syariah Di Indonesia, Cet Ke-2, Jakarta: Kencana, 2017.

Marinda, Wahyuni. Analisis Strategi Menghimpun Dana Zakat, Infak dan Sedekah Pada Rumah Zakat Cabang Palembang, Skripsi tidak diterbitkan (Palembang: Jurusan Ekonomi Islam Fakultas Ekonomi dan Bisnis Islam UIN Raden Fatah Palembang, 2016).

Moh. Khoirul Anam, Penerapan PSAK 101 Pada Laporan Dana Zakat dan DanaKebajikan,https://www.academi a.edu/33839690/Optimalisasi_Pengel olaan_Dana_Zakat_dan_Dana_Kebaji 
kan_pada_Bank_Syariah_Studi_Pen erapan_Standar_Akuntansi_Keuanga n_PSAK_101, pdf

Mubarok, Jaih. Modifikasi Hukum Islam Studi Tentang Qawl Qadim dam Qawl Jadid, Jakarta: PT RajaGrafindo Persada, 2002.

Muhammad. Metodologi Penelitian Ekonomi Islam: Pendekatan Kuantitatif

Jakarta: Rajawali Pers, 2008.

Muharto dan Ambarita, Arisandy. Metode Penelitian Sistem Informasi: Mengatasi Kesulitan Mahasiswa Dalam Menyususn Proposal Penelitian Yogyakarta: Deepublish, 2016.

Nasution, Ali Yusuf \& Qomaruddin, "Mekanisme Pengelolaan Dana Zakat, Infaq dan Shadaqah Di Bank Syariah Sebagai Implementasi Fungsi Sosial Bank (Studi Kasus Di BPR Syariah Amanah Ummah), Jurnal Syarikah 1, No.1, Juni (2015).

Partanto Pius, M. \& Al Barry Dahlan, Kamus Ilmuah Populer, Surabaya: Arloka. Sangid, Ahmad. Dasyatnya Sedekah Jakarta: Kultumedia, 2008.

Santoso, Sony. \& Agustino, Rinto. Zakat Sebagai Ketahanan Nasional, Yogyakarta: Deepublish, 2018.

Sari, Elsi Kartika. Pengantar Hukum Zakat dan Wakaf, Jakarta: PT Grasindo, 2006.

Soni, Santoso \& Rinto, Agustino. Zakat Sebagai Ketahanan Nasional Cet 1, Yogyakarta: Deepublish, 2018

Syaikh Abu Malik Kamal Bin As-Syyid Salim, Syaikh Abdullah Bin Abdul
Aziz Bin Bazz, Eksiklopedi Shaum \& Zakat, Cet, 1, Jawa Tengah: Cordova Mediatama, 2010.

Shihab, M. Quraish. Tafsir Al-Misbah: Pesan, Kesan dan Keserasian AlQur'an, Volume I; Jakarta: Lentera Hati, 2002.

Umam, Khotibul \& Antoni Very. Corporate Action Pembentukan Bank Syariah (Akuisisi, Konversi, dan Spin-Off), Yogyakarta: Gadjah Mada University Press, 2018.

Utomo, Setiawan Badi. Metode Praktik Penetapan Nisab Zakat, Bandung: PT Mizan Pustaka, 2009.

Vivin, Yenni Annor. Wahono, Budi. Analisis Perbandingan Kinerja Keuangan Bank Umum Syariah Dengan Bank Umum Konvensional Di Indonesia, Pdf, 20. E - Jurnal Riset Manajemenprodi Manajemen Fakultas Ekonomi Unisma.

Wirdyaningsih, Bank dan Asuransi Islam Di Indonesia, Jakarta: Kencana, 2005.

Wiroso, Penghimpunan Dana dan Distribusi Hasil Usaha Bank Syariah Jakarta:

PT Gramedia Widiasarana Indonesia, 2005. Yasin,

Panduan Zakat Dompet

Dhuafa, 10

https://www.dompetdhuafa.org/ uploads/media/PANDUAN-ZAKAT1433-web.pdf. 